Arq. Bras. Med. Vet. Zootec., v.64, n.4, p.887-890, 2012

\title{
Prevalence of hepatitis A virus in sea food in Iran
}

[Prevalência de vírus da hepatite A em frutos do mar no Irã]

\author{
H. Momtaz ${ }^{1}$, E. Rahimi ${ }^{1}$, S. Hajian ${ }^{2}$, M. Momeni ${ }^{3}$
}

\begin{abstract}
${ }^{1}$ Faculty of Veterinary Medicine ShahreKord Branch, Islamic Azad University - ShahreKord, Iran ${ }^{2}$ Student of Master of Science of Food Science \& Technology - Member of Young Researchers Club, ShahreKord Branch, Islamic Azad University, ShahreKord-Iran

${ }^{3}$ Biotechnology Research Center - ShahreKord Branch, Islamic Azad University, ShahreKord-Iran
\end{abstract}

\begin{abstract}
The objective of this study was to determine the prevalence of Hepatitis A Virus (HAV) in sea food samples in the Isfahan and Shahrekord townships in Iran. From September 2010 to April 2011, a total of 300 samples of fresh fish, shrimp, crab and lobster were obtained from randomly selected retail stores in the Isfahan and Shahrekord townships in Iran. The samples were tested for the presence of HAV using a reverse transcriptase- polymerase chain reaction method. Out of the total number of samples examined, 8 (2.7\%) were found to be positive for HAV. This virus was detected in 5\% and $1.7 \%$ of fresh fish and shrimp, respectively. This study shows the importance of sea food as potential sources of HAV infection in people in Iran.
\end{abstract}

Keywords: HAV, sea food, RT-PCR, Iran

\section{RESUMO}

O objetivo deste estudo foi determinar a prevalência do vírus Hepatitis A (HAV) em amostras de frutos do mar nas cidades de Isfahan e Shahrekord no Iran. De setembro de 2010 a Abril de 2011 um total de 300 amostras de peixe fresco, camarão, caranguejo e lagosta foram obtidas de lojas de varejo aleatoriamente escolhidas nas cidades de Isfahan e Shahrekord no Iran. As amostras foram testadas para presença de HAV usando o método de reação em cadeia em transcriptase reversa. Do total de amostras examinadas, $8(2.7 \%)$ foram positivas para HAV. Este vírus foi detectado em $5 \%$ e $1.7 \%$ de peixe fresco e camarão, respectivamente. Este estudo mostrou a importância de frutos do mar como fontes potenciais de infecção HAV em pessoas no Iran.

Palavras chave: HAV, frutos do mar, RT-PCR, Iran

\section{INTRODUCTION}

In developed countries, foodborne or waterborne hepatitis A (HA) outbreaks are relatively uncommon (Acheson and Fiore, 2004). However, infected food handlers remain the source of most reported foodborne outbreaks (Fiore, 2004). In many low endemicity countries, the potential for food contamination from an infected food handler is a recognized public health concern (Koopmans et al., 2003). In these countries, a large proportion of the population has never been exposed or vaccinated against hepatitis A virus (HAV) and is thus susceptible to infection during potential outbreaks (Scheifele, 2005; Tricco et al., 2006).

HAV may cause hepatitis 2-6 weeks after exposure. Infection and vaccination generally result in long-term immunity. In children, HAV infection is often asymptomatic. Symptoms of infection are more severe in older adults, with a case fatality rate of $0.8 \%$ in people aged $>40$ years of age (Brown and Persley, 2002). Transmission follows the fecal-oral route, and mainly occurs through contact with symptomatic or asymptomatic infected persons, i.e. person-to-

Recebido em 9 de agosto de 2011

Aceito em 31 de janeiro de 2012

E-mail: hamomtaz@yahoo.com 
person transmission. HAV has recently been recognized as a sexually transmitted infection, especially in men who have sex with men (MSM) (Urbanus et al., 2002).

Infection may also be foodborne, i.e. after ingestion of contaminated food. Underreporting of outbreaks due to foodborne sources is likely, as patients need to recall their exposures of 2-6 weeks preceding their illness. HAV is endemic in most countries in Africa, Asia, South America and Central America (Jacobsen and Koopman, 2004; Verhoef et al., 2011). For most Western countries such as the USA, Australia and countries in Europe, the risk of HAV outbreaks is changing because endemic circulation has become less common with the improvement of sanitary conditions. Consequently, the nonvaccinated population has become more susceptible (Koopmans et al., 2003).
Currently, there is limited information regarding the prevalence of foodborne viruses in sea food in Iran, so the objective of the present study was to determine the prevalence rate of HAV in sea food samples obtained from the Isfahan and Shahrekord townships in Iran using a RT-PCR assay.

\section{MATERIAL AND METHODS}

A total of 300 sea food samples were collected from September 2010 to April 2011 from supermarket and retail outlets in the Isfahan and Shahrekord townships in Iran. The sea food analysis was comprised of samples of fresh fish, crab, lobster and shrimp (Table 1). The samples were transferred to the Food Microbiology Laboratory at the Islamic Azad University of Shahrekord Branch in portable insulated coldboxes. Samples were analyzed on the day they were collected.

Table 1. Prevalence of HAV isolated from sea food in Iran

\begin{tabular}{cccc}
$\begin{array}{c}\text { Fish } \\
(\mathrm{n}=120)\end{array}$ & $\begin{array}{c}\text { Shrimp } \\
(\mathrm{n}=120)\end{array}$ & $\begin{array}{c}\text { Crab } \\
(\mathrm{n}=20)\end{array}$ & $\begin{array}{c}\text { Lobster } \\
(\mathrm{n}=40)\end{array}$ \\
\hline Infected samples & Infected samples & Infected samples & Infected samples \\
$6(5 \%)$ & $2(1.66 \%)$ & $0(0 \%)$ & $0(0 \%)$ \\
\hline
\end{tabular}

Two grams of inoculated mussel samples were rocked for $10 \mathrm{~min}$ with $1 \mathrm{~mL}$ of TRIzol ${ }^{\circledR}$ Reagent. The TRIzol ${ }^{\circledR}$ (Roche Applied Sciences) Reagent solution that reacted with the sample was kept separately. Another $1 \mathrm{~mL}$ TRIzol ${ }^{\circledR}$ Reagent was added to the sample rocked again for $10 \mathrm{~min}$ and was brought together with the previously collected TRIzol $^{\circledR}$ Reagent. The aqueous phase was taken after centrifugation $(8000 \mathrm{~g}, 20 \mathrm{~min}$, and $4^{\circ} \mathrm{C}$ ) and stored by freezing. A volume of $100 \mu \mathrm{L}$ was purified by the use of an RNeasy Mini kit (Qiagen) according to the manufacturer's instructions (Baert et al., 2007).

Oligonucleotides were purchased from Cinnagen (Cinnagen, Iran). Sequences of oligonucleotides for amplifying a fragment of 267, respectively, from the HAV (Robertson et al., 1992; Normann et al., 1994) were as follows:

2949: 5'- TATTTGTCTGTCACAGAACAATCAG -3' 3192: 5'- AGG AGGTGGAAGCACTTCATTTGA -3'

cDNA synthesis was carried out using moloney murine leukemia virus reverse transcriptase
(MMLV-RT, Fermentas) and random hexamer primers (Fermentas). Reverse transcription of heat-denatured RNA $\left(5 \mathrm{~min}\right.$ at $70^{\circ} \mathrm{C}$ in $32 \mu \mathrm{L}$ of reaction buffer for MMLV-RT in the presence of $0.1 \mathrm{mM}$ of each dATP, dCTP, dGTP and dTTP) was performed after the addition of $8 \mu \mathrm{L}$ of reaction mixture $(10 \mathrm{mM}$ dithiothreitol, $0.4 \mu \mathrm{g}$ of random hexamer, $5 \mathrm{U}$ of RNase inhibitor (Fermentas) and 400U of MMLV-RT) for $5 \mathrm{~min}$ at $22^{\circ} \mathrm{C}, 15 \mathrm{~min}$ at $37^{\circ} \mathrm{C}$ and $30 \mathrm{~min}$ at $42^{\circ} \mathrm{C}$. After reverse transcription, the reactions were heated to $99^{\circ} \mathrm{C}$ for $5 \mathrm{~min}$ in order to inactivate MMLVRT. Amplification of cDNA by PCR was carried out in a total volume of $50 \mu \mathrm{L}$ in the reaction buffer for Taq DNA polymerase containing $1 \mathrm{U}$ of Taq DNA polymerase (Fermentas), $1 \mu \mathrm{M}$ of each primer (2949 and 3192), $1 \mathrm{mM}$ $\mathrm{MgCl}_{2}, 0.15 \mathrm{mM} \mathrm{dNTP}$, and $4 \mu \mathrm{L}$ of cDNA. Amplification was performed in 40 cycles of denaturation at $95^{\circ} \mathrm{C}$ for $30 \mathrm{~s}$, annealing at $60^{\circ} \mathrm{C}$ for $1 \mathrm{~min}$ and extension at $72^{\circ} \mathrm{C}$ for $1 \mathrm{~min}$. After amplification, the PCR products were characterized through $1.5 \%$ agarose gel 
electrophoresis in Tris-borate-EDTA buffer (Kingsley and Richards, 2001).

Statistical analysis: Data were analyzed using SPSS ver. 16.0 statistical software, a Chi-square test and fisher's exact two-tailed test analysis was performed and differences were considered significant at values of $\mathrm{P}<0.05$.

\section{RESULTS}

According to results, 8 samples of total 300 studied samples were found to be infected with $\mathrm{HAV}$. The product of $267 \mathrm{bp}$ was obtained, as expected, from RT-PCR amplification of the amplicon encoded portions of HAV genome. The number of infected samples and percentage of infection are shown in Table 1. The infection rate was lower for HAV as no infection was found in crab and lobster.

\section{DISCUSSION}

A number of procedures have been reported for the detection of enteric viruses in sea food (Atmar et al., 1995; Cromeans et al., 1997; De Medici et al., 1998) and many of them have been applied to the study of viral contamination of shellfish from harvesting areas in different countries (Croci et al., 1999; Lee et al., 1999). Currently, there is limited information regarding the prevalence of enteric viruses in sea food in Iran. Therefore, the main purpose of the present study was to determine the prevalence rate of HAV in sea food samples obtained from the Shahrekord and Isfahan townships in Iran using a RT-PCR assay. In our study 6 out 120 (5\%) fish, and 2 out $120(1.7 \%)$ shrimp presented HAV. In the present study, no HAV isolate was detected in lobster and crab samples. To our knowledge, the present study is the first report of the detection of HAV in sea food in Iran; however, more research is needed to establish the prevalence rate of HAV in sea food.

The results of this study show that lobster and crab are not an important source for HAV infection in Iran. The sea food samples which were positive for HAV were collected from September to April. This result may indicate a potential point-source contamination.

The percentages of positive samples for HAV were similar to those obtained in other studies employing molecular detection procedures (Lee et al., 1999), however, higher contamination rates $(25 \%-85 \%)$ have also been reported (Romalde et al., 2002; Kittigul et al., 2010). Also, in Italy, according to the Italian National Epidemiological Surveillance System for Acute Hepatitis Viruses (SEIEVA, Sistema Epidemiologico Integrato per le Epatiti Virali Acute'), in the period from 1995 to $1997,71 \%$ of the noticed cases of acute viral hepatitis infection were cases of HAV infection. Variation in the prevalence of HAV isolates from sea food samples reported in other studies may be a result of different sampling techniques employed, seasonal effects and/or laboratory methodologies employed in different studies.

\section{CONCLUSIONS:}

The presence of HAV in some sea food indicates the potential risk of infection with HAV in people consuming raw and uncooked sea food products. Therefore high-risk groups should avoid previously prepared uncooked sea food.

\section{ACKNOWLEDGMENTS}

The authors thank Mr. M.D. Rahimian and S. Safari at the Biotechnology Research Center and Microbiology laboratory of the Islamic Azad University of Shahrekord for their technical support.

\section{REFERENCES}

ACHESON, D.W.; FIORE, A.E. Preventing foodborne disease-what clinicians can do. N. Engl. J. Med., v.350, p.437-440, 2004.

ATMAR, R.L.; NEILL, F.H.; ROMALDE, J.L. et al. Detection of Norwalk virus and hepatitis A virus in shellfish tissues with the PCR. Appl. Environ. Microbiol., v.61, p.3014-3018, 1995.

BAERT, L.; UYTTENDAELE, M.; DEBEVERE, J. Evaluation of two viral extraction methods for the detection of human noroviruses in shellfish with conventional and real-time reverse transcriptase PCR. Lett. Appl. Microbiol., v.44, p.106-111, 2007.

BROWN, G.R.; PERSLEY, K. Hepatitis A epidemic in the elderly. South Med. J., v.95, p.826-833, 2002.

CROCI, L.; DE MEDICI, D.; MORACE, G. et al. Detection of hepatitis A virus in shellfish by nested reverse transcription-PCR. Int. J. Food Microbiol., v.48, p.67-71, 1999. 
CROMEANS, T. L.; NAINAN, O.V.; MARGOLIS, H.S. Detection of hepatitis A virus RNA in oyster meat. Appl. Environ. Microbiol., v.63, p.2460-2463, 1997.

DE MEDICI, D.; BENEDUCE, F.; FIORE, A. et al. Application of reverse transcriptase-nested-PCR for detection of poliovirus in mussels. Int. J. Food Microbiol., v.40, p.51-56, 1998.

FIORE, A.E. Hepatitis A transmitted by food. Clin. Infect. Dis., v.38, p.705-715, 2004.

JACOBSEN, K.H.; KOOPMAN, J.S. Declining hepatitis A seroprevalence: a global review and analysis. Epidemiol. Infect., v.132, p.1005-1022, 2004.

KINGSLEY, D.H.; RICHARDS, G.P. Rapid and efficient extraction method for reverse transcriptionPCR detection of hepatitis A and Norwalk-like viruses in shellfish. Appl. Environ. Microbiol., v.67, p.41524157, 2001.

KITTIGUL, L.; POMBUBPA, K.; SUKONTHALUX, S. et al. Detection of hepatitis A virus and bacterial contamination in raw oysters in Thailand. Southeast Asian J. Trop. Med. Public Health, v.41, p.105-113, 2010.

KOOPMANS, M.; VENNEMA, H.; HEERSMA, H. et al. Early identification of common-source foodborne virus outbreaks in Europe. Emerg. Infect. Dis., v.9, p.1136-1142, 2003.

LEE, T.; YAM, W.C.; TAM, T.Y. et al. Occurrence of Hepatitis A virus In green-lipped mussels (Perna Viridis). Water Res., v.33, p.885-889, 1999.
NORMANN, A.; GRAFF, J.; FLEHMIG, B. Detection of hepatitis A virus in a factor VIII preparation by antigen capture/PCR. Vox Sang., v.67, p.57-60, 1994.

ROBERTSON, B.H.; JANSEN, R.W.; KHANNA, B. et al. Genetic relatedness of hepatitis A virus strains recovered from different geographical regions. J. Gen. Virol., v.73, p.1365-1377, 1992

ROMALDE, J.L.; AREA, E.; SÁNCHEZ, G. et al. Prevalence of enterovirus and hepatitis $\mathrm{A}$ virus in bivalve molluscs from Galicia (NW Spain): inadequacy of the EU standards of microbiological quality. Int. J. Food Microbiol., v.74, p.119-130, 2002.

SCHEIFELE, D.W. Hepatitis A vaccines: the growing case for universal immunisation of children. Expert Opin. Pharmacother., v.6, p.157-164, 2005.

TRICCO, A.C.; PHAM, B.; DUVAL, B. et al. A review of interventions triggered by hepatitis A infected food-handlers in Canada. BMC Health Serv. Res., v.6, p.157, 2006.

URBANUS, A.T.; VAN HOUDT, R.; JW VAN DE LAAR, T.; COUTINHO, R.A. Viral hepatitis among men who have sex with men, epidemiology and public health consequences. South Med. J., v.95, p.826-833, 2002.

VERHOEF, L.; BOOT, H.J.; KOOPMANS, M. et al. Changing risk profile of hepatitis $\mathrm{A}$ in The Netherlands: a comparison of seroprevalence in 19951996 and 2006-2007. Epidemiol. Infect., v.13, p.1-9, 2011. 